\title{
Recent advances in understanding mesenchymal stromal
}

\section{cells [version 1; peer review: 3 approved]}

\author{
Erika Rendra ${ }^{1 *}$, Eleonora Scaccia ${ }^{*}$, Karen Bieback (iD)1-3 \\ ${ }^{1}$ Institute of Transfusion Medicine and Immunology, Mannheim Institute of Innate Immunoscience, Medical Faculty Mannheim, \\ Heidelberg University, Mannheim, 68167, Germany \\ ${ }^{2}$ FlowCore Mannheim, Medical Faculty Mannheim, Heidelberg University, Mannheim, 68167, Germany \\ ${ }^{3}$ German Red Cross Blood Donor Service Baden-Württemberg - Hessen, Mannheim, 68167, Germany \\ ${ }^{*}$ Equal contributors
}

V1 First published: 27 Feb 2020, 9(F1000 Faculty Rev):156

https://doi.org/10.12688/f1000research.21862.1

Latest published: 27 Feb 2020, 9(F1000 Faculty Rev):156

https://doi.org/10.12688/f1000research.21862.1

\begin{abstract}
Mesenchymal stromal cells (MSCs) are among of the most studied cell type for cellular therapy thanks to the ease of isolation, cultivation, and the high ex vivo expansion potential. In 2018, the European Medicines Agency finally granted the first marketing authorization for an MSC product. Despite the numerous promising results in preclinical studies, translation into routine practice still lags behind: therapeutic benefits of MSCs are not as satisfactory in clinical trial settings as they appear to be in preclinical models. The bench-tobedside-and-back approach and careful evaluation of discrepancies between preclinical and clinical results have provided valuable insights into critical components of MSC manufacturing, their mechanisms of action, and how to evaluate and quality-control them. We sum up these past developments in the introductory section ("Mesenchymal stromal cells: name follows function"). From the huge amount of information, we then selected a few examples to illustrate challenges and opportunities to improve MSCs for clinical purposes. These include tissue origin of MSCs, MSC culture conditions, immune compatibility, and route of application and dosing. Finally, we add some information on MSC mechanisms of action and translation into potency assays and give an outlook on future perspectives raising the question of whether the future clinical product may be cell-based or cell-derived.
\end{abstract}

\section{Keywords}

mesenchymal stromal cells, translation, clinical perspectives, secretome, extracellular vesicles

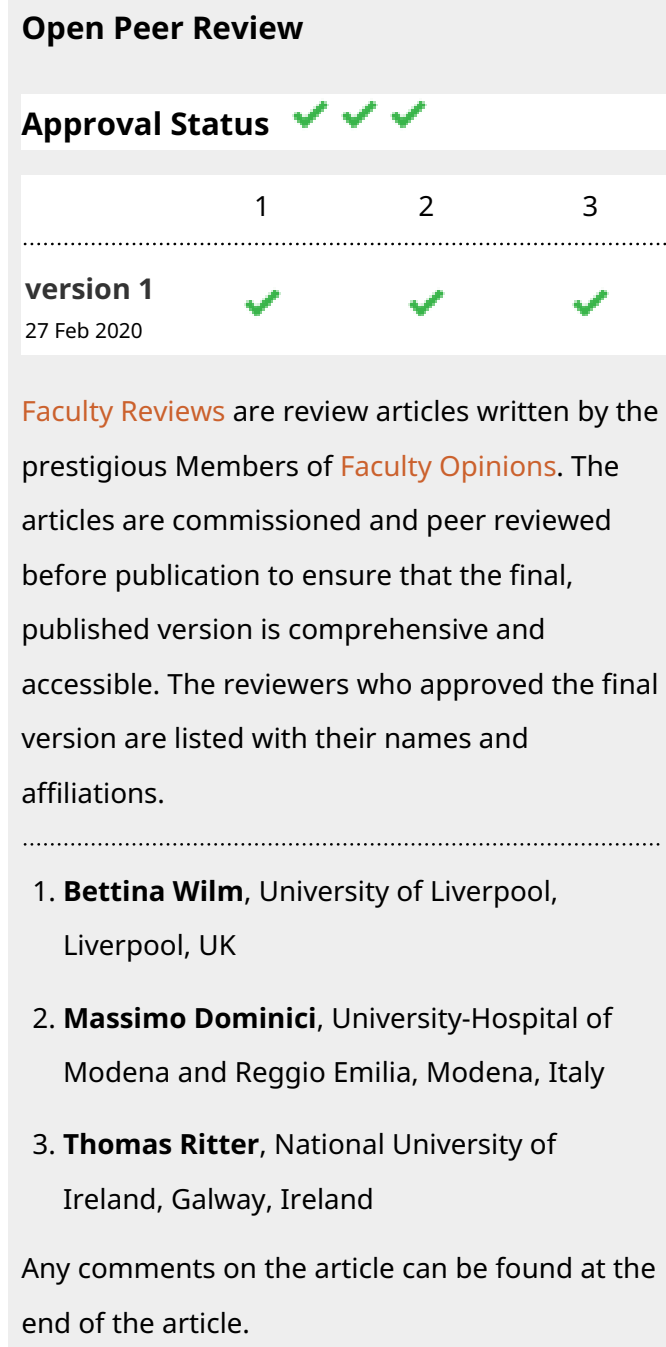

1. Bettina Wilm, University of Liverpool, Liverpool, UK

2. Massimo Dominici, University-Hospital of Modena and Reggio Emilia, Modena, Italy

3. Thomas Ritter, National University of Ireland, Galway, Ireland Any comments on the article can be found at the end of the article. 
Corresponding author: Karen Bieback (Karen.Bieback@medma.uni-heidelberg.de)

Author roles: Rendra E: Conceptualization, Writing - Original Draft Preparation, Writing - Review \& Editing; Scaccia E:

Conceptualization, Writing - Original Draft Preparation, Writing - Review \& Editing; Bieback K: Conceptualization, Writing - Original Draft Preparation, Writing - Review \& Editing

Competing interests: No competing interests were disclosed.

Grant information: We acknowledge funding from the European Union's Horizon 2020 research and innovation programme under Marie Skłodowska-Curie grant agreement number 813839.

The funders had no role in study design, data collection and analysis, decision to publish, or preparation of the manuscript.

Copyright: @ 2020 Rendra E et al. This is an open access article distributed under the terms of the Creative Commons Attribution License , which permits unrestricted use, distribution, and reproduction in any medium, provided the original work is properly cited.

How to cite this article: Rendra E, Scaccia E and Bieback K. Recent advances in understanding mesenchymal stromal cells [version 1; peer review: 3 approved] F1000Research 2020, 9(F1000 Faculty Rev):156 https://doi.org/10.12688/f1000research.21862.1

First published: 27 Feb 2020, 9(F1000 Faculty Rev):156 https://doi.org/10.12688/f1000research.21862.1 


\section{Mesenchymal stromal cells: name follows function}

In 2018, the first marketing authorization for a mesenchymal stromal cell (MSC) product was granted by the European Medicines Agency for the treatment of complex perianal fistulas in patients with Crohn's disease ${ }^{1}$. From a regulatory perspective, MSCs are classified as an advanced therapy medicinal product (ATMP) (https://www.ema.europa.eu/en/human-regulatory/ overview/advanced-therapy-medicinal-products-overview). This represents a milestone in the long history of MSCs, which were first described in 1867 by Cohnheim as non-hematopoietic bone marrow-derived cells to migrate through the bloodstream to distant sites of injury and participate in tissue regeneration ${ }^{2}$. In the $1970 \mathrm{~s}$, Friedenstein et al. characterized them as a minor subpopulation of marrow-derived plastic adherent cells with osteogenic and hematopoietic supportive potential ${ }^{3}$. He also established the term colony-forming unit-fibroblast. In the 1990s, Caplan",5 and Pittenger et al. ${ }^{4}$ coined the term "mesenchymal stem cells" on the basis of the multi-lineage differentiation potential of these cells. At this time, controversy arose as to whether these cells are stem cells or not. Bianco and Robey and colleagues used the term "skeletal stem cells" for cells residing in the postnatal bone marrow and giving rise to cartilage, bone, hematopoiesis-supportive stroma, and marrow adipocytes in defined in vivo assays ${ }^{7-9}$. In 2006, to put an end to the discussion, the International Society for Cell and Gene Therapy defined the term "mesenchymal stromal cells" and set up minimal criteria defining (bone marrow-derived) MSCs (Table 1$)^{10}$. At that time, it became evident that MSCs (or at least cells with similar characteristics) could be isolated from a variety of different tissues, suggesting a perivascular origin $^{11,12}$. Given the similarity to fibroblasts, Haniffa et al. asked: "Mesenchymal stem cells: The fibroblasts' new clothes?"13. However, with the increasing use in (pre)clinical studies, it became evident that apparently not the proposed multi-lineage differentiation potential but rather their secreted bioactive molecules that modulate immune and inflammatory responses were key to exerting therapeutic effects (in fact, only few

\section{Table 1. Definition of mesenchymal stromal cell.}

\begin{tabular}{|l|l|l|}
\hline $\begin{array}{l}\text { Adherence to } \\
\text { plastic }\end{array}$ & $\begin{array}{l}\text { Specific surface } \\
\text { markers }\end{array}$ & $\begin{array}{l}\text { In vitro multipotent } \\
\text { differentiation potential }\end{array}$ \\
\hline & Positive: & $\begin{array}{l}\text { Osteoblasts } \\
\text { Cdipocytes }\end{array}$ \\
\hline & CD105 & Chondroblasts \\
CD90 & \\
& Negative: & \\
CD45 & \\
CD34 & \\
CD14 & \\
CD11b & \\
CD79a & \\
CD19 & \\
HLA class I & \\
\hline
\end{tabular}

The minimal criteria defining the mesenchymal stromal cell by the International Society for Cell and Gene Therapy (according to 10). transplanted cells were found in vivo to be engrafted and differentiated $)^{14,15}$. Thus, Caplan introduced the term "medicinal signaling cells" to illustrate their versatility and flexibility to adapt to the local milieu ${ }^{16}$. We interpret the abbreviation "MSCs" as "mesenchymal stromal cells" as, according to our own experimental observations, the cells do not fulfil "stem cell" criteria such as indefinite self-renewal.

Despite arguments about the most appropriate name, MSCs have emerged as the most intensely studied cell type for experimental cell therapy. Starting with the first use in patients in a hematological transplant setting ${ }^{17}$, numerous clinical indications have been investigated, ranging from hematological disorders (including graft-versus-host disease, or GvHD), bone/cartilage defects, diabetes, cardiovascular and neurological diseases (including autoimmune diseases), and liver and renal disease $^{18-20}$. The ease of isolation, cultivation, and the high ex vivo expansion potential in line with the numerous therapeutic mechanisms (paracrine pro-regenerative, anti-fibrotic, antiapoptotic, pro-angiogenic, and immunomodulatory functions) have contributed to this broad exploitation.

\section{Challenges and opportunities to improve mesenchymal stromal cells for clinical purposes}

Despite the promising results in preclinical studies, therapeutic benefits of MSCs are not as satisfactory in clinical trial settings ${ }^{21}$. This section addresses some factors that might contribute to this disparity and how to improve the therapeutic capacity of MSCs (Figure 1).

Tissue origin of mesenchymal stromal cells

The most prevalent source for MSCs is adult bone marrow ${ }^{18}$. Adipose tissue is emerging as an important source, as exemplified

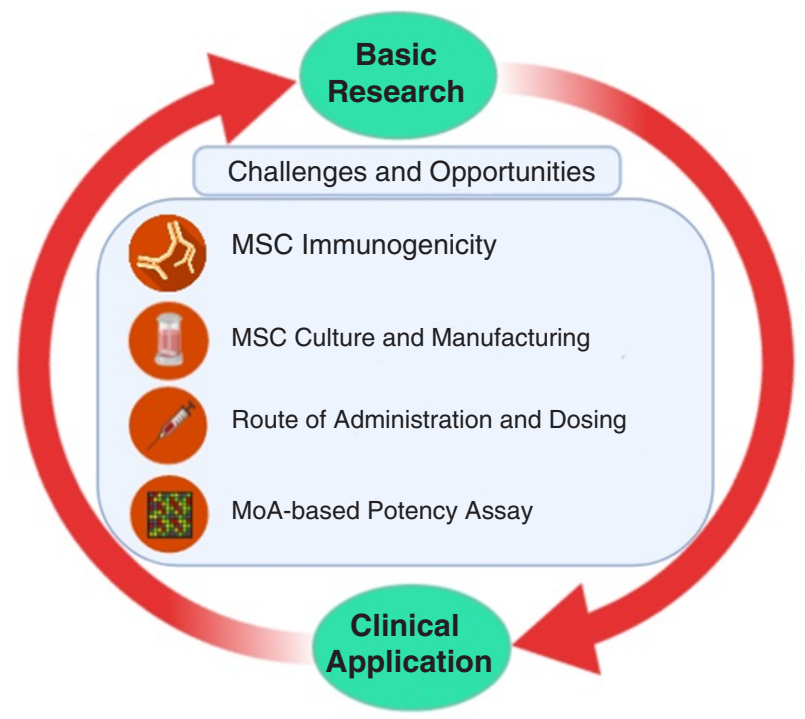

Figure 1. Bench-to-bedside-and-back. Challenges and opportunities in translating mesenchymal stromal cell (MSC)-based therapy from basic research to clinical practices, including immunogenicity of MSCs, Good Manufacturing Practice-compliant MSC manufacturing as well as determining the route of administration and dosing. MoA, mechanism of action. 
by the ATMP granted marketing authorization by the European Medicines Agency (mentioned above). We and others have tried to understand how interchangeable MSCs from different tissue sources are and whether one may be more suitable for certain disease entities than for others. The observed differences suggest an "environmental niche memory", which could help to select the most appropriate tissue source for a certain clinical indication ${ }^{12,22-26}$.

\section{Mesenchymal stromal cell culture conditions and cellular} fitness

Usage of fetal bovine serum (FBS) as culture supplement has been a major issue in MSC production ${ }^{27}$. The growing concern relates to transmission of pathogens such as prions and possible immune reactions against xenogeneic agents ${ }^{28,29}$. Consequently, as a replacement of FBS, other supplements have been introduced. One of the most common is platelet lysate $(\mathrm{PL})^{29-31}$, as it contains growth factors suitable to support MSC ex vivo expansion without causing genomic instability ${ }^{32}$. However, the use of PL is not without concerns: batch-to-batch variation and pathogen reduction need to be addressed to standardize PL use in MSC manufacturing ${ }^{33}$.

MSC culture conditions differ enormously, hampering comparability of data ${ }^{34}$. Cellular "fitness" is considered the most critical parameter and is influenced by cellular/replicative age and potential "cryo-injury" $21,35,36$.

Expansion of MSCs in vitro, required to achieve clinical doses (see below), ultimately results in replicative senescence that compromises therapeutic efficacy ${ }^{37,38}$. Thus, genomic stability should be addressed as a safety measure before clinical application $^{39}$. In addition, the thawing of cryopreserved MSCs just before transplantation may hamper their therapeutic capacity. In most animal experiments, MSCs are harvested freshly before the transplantation, while on the peak of the replicative phase. Meanwhile, in clinical trial, most MSCs are prebanked and expanded to their proliferative limit, frozen down, and just thawed prior the transplantation ${ }^{35,40}$. Following retrieval from liquid nitrogen, MSCs have been shown to undergo a heat shock response ("cryo stun effect") leading to cell injury for at least the first 24 hours $^{40}$. This has been shown to compromise immune-modulation function, enhance vulnerability to lysis by immune cells and the complement system, and decrease in vivo persistence upon intravenous administration ${ }^{40}$. A rescue culture for a few days could eventually reduce this "cryo stun effect".

As it has become clear that culture conditions can greatly affect MSC function, it also opens a new window for MSC priming to improve their therapeutic efficacy. A growing body of data report a wide array of priming approaches, from usage of cytokines, growth factors, hypoxia, pharmaceutical drugs, and 3D culture using biomaterials ${ }^{41,42}$. For example, MSC priming with interferon-gamma (IFN- $\gamma$ ) is considered key to suppress T-cell proliferation, partly through production of indolamine-2,3dioxygenase (IDO) and programmed cell death-1 ligand (PDL-1) upregulation $^{43}$. Indeed, allogeneic infusion of IFN- $\gamma$-primed
MSCs to non-obese diabetic/severe combined immunodeficiency (NOD/SCID) mice reduced GvHD symptoms ${ }^{44}$. However, MSC priming with IFN- $\gamma$ should be carried out with caution as it can upregulate the expression of HLA class I and II molecules, which could affect immune compatibility ${ }^{45}$.

Lastly, another challenge to bring MSCs to clinical application is upscaling of MSC culture. A number of strategies for upscaling cell, secretome, or extracellular vesicle production have been reported and reviewed extensively ${ }^{46-48}$. However, economically feasible approaches that meet Good Manufacturing Practice compliance have yet to be standardized ${ }^{49}$.

\section{Route of application and dosing}

Depending on the clinical purposes, MSCs are administered differently, either systemically infused or locally injected. Contrary to the old belief that MSCs migrate to the site of injury and replace the injured tissue once MSCs are injected intravenously, they are mostly trapped in lungs and die within 24 hours $^{50}$. Pulmonary embolism and infarct of three related patients have been reported after adipose MSC infusion ${ }^{51}$. MSCs express tissue factor, a cell surface glycoprotein that plays an important role in extrinsic coagulation, which by triggering procoagulation has led to thromboembolic events after MSC infusion. Thus, adding an anti-coagulant during the infusion should be considered ${ }^{52}$.

The majority of preclinical studies using mice and rats infuse around 50 million and 10 to 20 million MSCs per kilogram of body weight, respectively ${ }^{53,54}$. Meanwhile, the average number of MSCs transfused intravenously is 100 million per patient, corresponding to 1 to 2 million per kilogram of body weight ${ }^{55}$. This may in part explain the huge discrepancy of outcome between preclinical and clinical studies, assuming that the therapeutic benefit is dose-dependent ${ }^{21}$. Although the notion of increasing MSC dose might be tempting, safety should be assessed carefully for it might, for example, increase the risk for embolism or adverse reactions. In addition, the lack of standardized pharmacodynamics and pharmacokinetics models applied to MSCs represents a limiting factor ${ }^{56}$.

Another potential explanation for the translational gap between clinical and preclinical data is that, in patients, the degree of severity might be too high for MSC therapy to be as efficacious as in animal studies. In order to get better clinical outcomes, MSC-based therapy may be considered as prevention treatment together with first-line therapy and not only as salvage or even palliative therapy. However, this notion will require proper risk-benefit evaluation and support from ethics committees.

\section{Hemocompatibility and immune compatibility}

For a long time, MSCs have been considered to be immuneprivileged, allowing their transplantation across histocompatibility barriers ${ }^{57}$. Recent data, however, indicate that MSC transplantation may provoke donors' humoral and cellular immune responses, especially in allogeneic settings ${ }^{21,58}$. In GvHD, in fact, this immune recognition appears to be fundamental for the therapeutic effect: MSCs recognized by cytotoxic $\mathrm{T}$ cells 
undergo apoptosis and are phagocytosed by macrophages which subsequently elicit immunosuppression via prostaglandin $\mathrm{E}_{2}\left(\mathrm{PGE}_{2}\right)$ and IDO activities ${ }^{59-61}$.

MSCs have also been shown to elicit an instant blood-mediated inflammatory reaction (IBMIR) in both a cell dose- and a donordependent manner ${ }^{62}$. Non-bone marrow-derived MSCs appear to express higher levels of pro-coagulant tissue factor, which makes them more likely to induce $\mathrm{IMBIR}^{63}$. Adding anticoagulants during MSC transplantation may be a good option for clinical application ${ }^{36,52}$. Likewise, the selection of tissue factor-negative or low expressing MSCs has been proposed as a strategy to improve hemocompatibility ${ }^{63}$.

Moreover, allogeneic MSC transplantation can provoke an adaptive immune response in mice through increased T-cell memory and allo-antibodies ${ }^{64,65}$. The latter may be associated with complement-mediated cytotoxicity ${ }^{58}$. Yet only two clinical trials ${ }^{1,67}$ report the development of donor-specific antibodies in patients who have received allogeneic $\mathrm{MSCs}^{66}$. But the authors argue that the increased allo-antibodies have no relevance in the clinical outcome or the occurrence of adverse events ${ }^{1,67}$. Moreover, in two other clinical trials, which used allogeneic MSCs to treat type 2 diabetes and diabetic nephropathy, there was no report of patients developing donor-specific HLA antibodies despite donor-recipient mismatching ${ }^{68,69}$. Although the results from clinical studies seem encouraging, the scarcity of studies elucidating possible allo-immune reactions may cause a bias in the observed trend ${ }^{66}$. The occurrence of FBS (used as culture supplement for cell expansion)-specific antibodies has prompted the search for alternative and improved culture conditions as described above $\mathrm{e}^{70}$.

\section{Mechanisms of action}

Mesenchymal stromal cell secretome

The MSC secretome is composed of different soluble factors, including cytokines, growth factors, chemokines, immunomodulatory molecules, cell organelles, and nucleic acids, which are produced, some of these eventually encapsulated in extracellular vesicles, and secreted or directly transferred to neighboring cells ${ }^{71,72}$. These factors can modulate the immune system, inhibit cell death and fibrosis, stimulate vascularization, and promote tissue remodeling (Figure 2) ${ }^{73}$. MSCs can adapt efficiently to the local milieu and change their secretome ${ }^{74}$. On one hand, this significantly hampers the understanding of their mechanisms of action (MoAs) in vivo and the establishment of predictive and quantitative potency assays. On the other hand, it paves the way to potentially improve therapeutic efficacy (for example, the preconditioning with different factors that activate very specific signaling pathways). Treating MSCs in vitro with hypoxia, 3D culture, or soluble factors such as stromal cellderived factor 1 (SDF-1) or transforming growth factor-beta (TGF- $\beta$ ) triggers Akt, ERK, and p38MAPK signaling pathways. These pathways, at the same time, can induce the production of cytoprotective molecules (catalase, heme oxygenase-1, and so on), pro-regenerative (basic fibroblast growth factor, hepatocyte growth factor, insulin-like growth factor-1, and so on) and proangiogenic (vascular endothelial growth factor, or VEGF) factors, and also immunomodulatory cytokines (IDO, PGE ${ }_{2}$, interleukin-6, and so on $)^{42,71}$.

\section{Extracellular vesicles}

Extracellular vesicles (EVs) are further candidates to explain the therapeutic effects of MSCs. EVs are membrane-enclosed particles of different sizes (exosomes, microvesicles, and apoptotic bodies) released by cells in the plasma and other body fluids $^{75,76}$. EVs transport biologically active molecules and genetic information to target cells, influencing their function ${ }^{77}$. Thanks to these characteristics, EVs are also emerging as biomarkers for various diseases ${ }^{78}$. EVs carry a wide variety of genetic material, in particular microRNAs, which play an important role in the biological function of EVs. These small RNAs regulate the cell cycle and migration (for example, miR191, miR-222, miR-21, and let-7a), inflammation (for example, miR-204-5p), and angiogenesis (for example, miR-222 and miR-21). In a new therapeutic approach, MSC-derived EVs

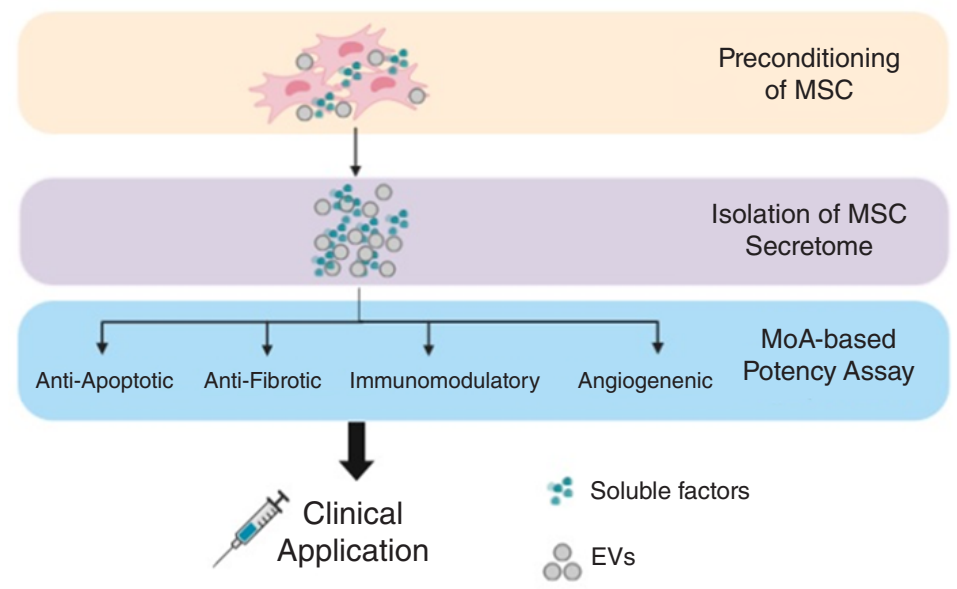

Figure 2. Mesenchymal stromal cell (MSC) secretome in clinical application. Strategies to harness the MSC secretome for clinical purposes include preconditioning/priming of MSCs to manipulate their paracrine factors, isolation of the secretome, and establishing MoAbased potency assay. EV, extracellular vesicle; MoA, mechanism of action. 
are being engineered by increasing or modifying their content (proteins or RNA $)^{77}$. As an example, an effective drug delivery system for wound healing in diabetes was developed by transfecting non-coding RNA (Lnc-RNA-H19) into EVs ${ }^{79}$. Based on these data, some researchers suggest that the conditioned medium or even EVs should be used as drugs rather than $\mathrm{MSCs}^{80}$.

In some circumstances (for example, GvHD mentioned above), dead or dying cells may contribute to therapeutic efficacy. Thus, an improved understanding on MSC "necrobiology" has been proposed, considering apoptosis, autophagy, mitochondrial transfer, and also vesicles ${ }^{61}$. Recognition by the innate immune system in different disease contexts may be key to understand and improve MSC function ${ }^{60,81}$.

\section{Potency assays}

For advanced clinical trials, assays that can verify MSC identity and quality and can predict their functionality in vivo are required ${ }^{82}$. Owing to the manifold functions of MSCs and their rapid adaptation to the local milieu, which may modify their function at sites of injury, disease, or inflammation, assays to predict these functions in vivo are hard to develop.

Agreed quality-control criteria include the determination of presence and absence of certain surface markers and of MSC differentiation potential, their senescence status, their secretome and immunomodulatory functions. In addition, surrogate assays which more specifically test the proposed therapeutic mechanism of action, for example angiogenesis have been established $^{83-87}$. The group of Galipeau was the first to suggest a combinatorial assay matrix as a platform to integrate different assays $^{88,89}$. In the first study, they employed secretome analysis and quantitative RNA-based array to estimate the immunomodulatory capacity of MSCs and their crosstalk with peripheral blood mononuclear cells (PBMCs), in which CXCL9, CXCL10, VEGF, and CCL2 secretion and expression were correlated with suppression of T-cell proliferation ${ }^{88}$. The other study investigated the phosphorylation of signal transducer and activator of transcription (STAT) in MSC-PBMC co-culture settings where STAT1 and STAT3 phosphorylation was associated with MSC immunoinhibitory capacity ${ }^{89}$. Moreover, Phinney et al. reported a "Clinical Indications Prediction Scale" that, based on Twist-1 expression levels, could predict therapeutic efficacy: high levels of Twist-1 predict higher angiogenic potential, whereas low levels are in line with improved antiinflammatory and immunosuppressive actions ${ }^{90}$.

We expect rapid progress in the development of combinatorial potency assays based on the increasing knowledge of MSC biology (omics, including single-cell analyses) ${ }^{91,92}$. Integrating this more comprehensive insight into MSC heterogeneity with MSC molecular signatures and their highly complex interaction with the local microenvironment in line with a better understanding of molecular mechanisms of action in various pathological settings will hopefully enable easy-to-perform assays with predictive value.

\section{Future perspectives}

The key questions for the future may be, do we need cells? Do we need viable cells, or do apoptotic cells and subcellular components such as EVs, or mitochondria, or just the secretome do a similar job?

The biological properties of the MSC secretome and how it orchestrates MSC immunomodulatory and regenerative capacity in the disease context remain enigmatic, prompting further studies. Moreover, given the possibility of modulating MSCs and their secretome, a disease-specific MSC priming (for instance, with pro-inflammatory cytokines) may improve efficacy.

Lastly, in order to standardize MSC therapy and avoid outcome bias, rigorous potency assays are needed. However, the selection of specific potency assays, whether it is a disease-specific (for example, angiogenesis and immunomodulation) or a more general (for example, proliferation) evaluation of MSC function that can be used regardless of diseases' pathophysiology, needs further elucidation.

Given the enormous knowledge gain in MSCs over the past years, largely obtained by bench-to-bedside-and-back approaches and recapitulated by the continuous adaptation of the term MSCs ("name follows function"), we expect the development of novel translational strategies. A better understanding of failures, the identification and consequent mitigation of challenges and finally an improved understanding of MoAs, translating into robust potency assays, will be key for a successful translation of MSCs into clinical practice.
1. F Panés J, García-Olmo D, van Assche G, et al:: Expanded allogeneic adiposederived mesenchymal stem cells (Cx601) for complex perianal fistulas in Crohn's disease: A phase 3 randomised, double-blind controlled trial. Lancet. 2016; 388(10051): 1281-90.

PubMed Abstract | Publisher Full Text | F1000 Recommendation

2. Cohnheim J: Ueber Entzündung und Eiterung. Archiv f pathol Anat. 1867; 40: $1-79$.

Publisher Full Tex
3. Friedenstein AJ, Chailakhyan RK, Latsinik NV, et al.: Stromal cells responsible for transferring the microenvironment of the hemopoietic tissues. Cloning in vitro and retransplantation in vivo. Transplantation. 1974; 17(4): 331-40. PubMed Abstract | Publisher Full Text

4. Caplan Al: Mesenchymal stem cells. J Orthop Res. 1991; 9(5): 641-50. PubMed Abstract | Publisher Full Text

5. Caplan Al: The mesengenic process. Clin Plast Surg. 1994; 21(3): 429-35. PubMed Abstract 
6. Pittenger MF, Mackay AM, Beck SC, et al:: Multilineage potential of adult human mesenchymal stem cells. Science. 1999; 284(5411): 143-7. PubMed Abstract | Publisher Full Text

7. Bianco P, Robey PG, Simmons PJ: Mesenchymal Stem Cells: Revisiting History, Concepts, and Assays. Cell Stem Cell. 2008; 2(4): 313-9. PubMed Abstract | Publisher Full Text | Free Full Text

8. Kuznetsov SA, Mankani MH, Gronthos S, et al:: Circulating Skeletal Stem Cells. J Cell Biol. 2001; 153(5): 1133-40. PubMed Abstract | Publisher Full Text | Free Full Text

9. $\mathrm{F}$ Bianco $\mathrm{P}, \mathrm{Cao} X$, Frenette PS: et al:The meaning, the sense and the significance: Translating the science of mesenchymal stem cells into medicine. Nat Med. 2013; 19(1): 35-42.

PubMed Abstract | Publisher Full Text | Free Full Text | F1000 Recommendation

10. F Dominici M, Le Blanc K, Mueller I, et al.: Minimal criteria for defining multipotent mesenchymal stromal cells. The International Society for Cellular Therapy position statement. Cytotherapy. 2006; 8(4): 315-7. PubMed Abstract | Publisher Full Text | F1000 Recommendation

11. F Crisan M, Yap S, Casteilla L, et al:: A Perivascular Origin for Mesenchymal Stem Cells in Multiple Human Organs. Cell Stem Cell. 2008; 3(3): 301-13. PubMed Abstract | Publisher Full Text | F1000 Recommendation

12. Kern S, Eichler H, Stoeve J, et al.: Comparative Analysis of Mesenchymal Stem Cells from Bone Marrow, Umbilical Cord Blood, or Adipose Tissue. Stem Cells. 2006; 24(5): 1294-301. PubMed Abstract | Publisher Full Text

13. Haniffa MA, Collin MP, Buckley CD, et al:: Mesenchymal stem cells: The fibroblasts' new clothes? Haematologica. 2009; 94(2): 258-63. PubMed Abstract | Publisher Full Text | Free Full Text

14. Fiori A, Terlizzi $\mathrm{V}$, Kremer $\mathrm{H}$, et al.: Mesenchymal stromal/stem cells as potentia therapy in diabetic retinopathy. Immunobiology. 2018; 223(12): 729-43. PubMed Abstract | Publisher Full Text

15. Torres Crigna A, Daniele C, Gamez C, et al:: Stem/Stromal Cells for Treatment of Kidney Injuries With Focus on Preclinical Models. Front Med (Lausanne). 2018; 5: 179 .

PubMed Abstract | Publisher Full Text | Free Full Text

16. Caplan Al: MSCs: The Sentinel and Safe-Guards of Injury. J Cell Physiol. 2016; 231(7): 1413-6. PubMed Abstract | Publisher Full Text

17. Lazarus HM, Haynesworth SE, Gerson SL, et al: Ex vivo expansion and subsequent infusion of human bone marrow-derived stromal progenitor cells (mesenchymal progenitor cells): Implications for therapeutic use. Bone Marrow Transplant. 1995; 16(4): 557-64. PubMed Abstract

18. Sharma RR, Pollock K, Hubel A, et al.: Mesenchymal stem or stromal cells: A review of clinical applications and manufacturing practices. Transfusion. 2014; 54(5): 1418-37.

PubMed Abstract | Publisher Full Text | Free Full Text

19. Andrzejewska A, Lukomska B, Janowski M: Concise Review: Mesenchymal Stem Cells: From Roots to Boost. Stem Cells. 2019; 37(7): 855-64. PubMed Abstract | Publisher Full Text | Free Full Text

20. Schäfer R: Advanced cell therapeutics are changing the clinical landscape: Will mesenchymal stromal cells be a part of it? BMC Med. 2019; 17(1): 53 PubMed Abstract | Publisher Full Text | Free Full Text

21. Galipeau J, Sensébé L: Mesenchymal stromal cells: clinical challenges and therapeutic opportunities. Cell Stem Cell. 2018; 22(6): 824-33. PubMed Abstract | Publisher Full Text | Free Full Text

22. Mattar P, Bieback K: Comparing the Immunomodulatory Properties of Bone Marrow, Adipose Tissue, and Birth-Associated Tissue Mesenchymal Stromal Cells. Front Immunol. 2015; 6: 560. PubMed Abstract | Publisher Full Text | Free Full Text

23. Paliwal S, Chaudhuri R, Agrawal A, et al.: Human tissue-specific MSCs demonstrate differential mitochondria transfer abilities that may determine their regenerative abilities. Stem Cell Res Ther. 2018; 9(1): 298. PubMed Abstract | Publisher Full Text | Free Full Text

24. Pittenger MF, Discher DE, Péault BM, et al:: Mesenchymal stem cell perspective: cell biology to clinical progress. NPJ Regen Med. 2019; 4: 22 PubMed Abstract | Publisher Full Text | Free Full Text

25. Ragni E, Montemurro T, Montelatici E, et al.: Differential microRNA signature of human mesenchymal stem cells from different sources reveals an "environmental-niche memory" for bone marrow stem cells. Exp Cell Res. 2013; 319(10): 1562-74

PubMed Abstract | Publisher Full Text

26. de Almeida DC, Ferreira MRP, Franzen J, et al: Epigenetic Classification of Human Mesenchymal Stromal Cells. Stem Cell Reports. 2016; 6(2): 168-75. PubMed Abstract | Publisher Full Text | Free Full Text

27. van der Valk J, Bieback K, Buta C, et al:: Fetal Bovine Serum (FBS): Past - Present - Future. ALTEX. 2018; 35(1): 99-118. PubMed Abstract | Publisher Full Text

28. Bieback K: Platelet lysate as replacement for fetal bovine serum in mesenchymal stromal cell cultures. Transfus Med Hemother. 2013; 40(5): 326-35. PubMed Abstract | Publisher Full Text | Free Full Text

29. Burnouf T, Strunk D, Koh MB, et al.: Human platelet lysate: Replacing fetal bovine serum as a gold standard for human cell propagation? Biomaterials.
2016; 76: 371-87.

PubMed Abstract | Publisher Full Text

30. Phinney DG, Galipeau J: Manufacturing mesenchymal stromal cells for clinical applications: A survey of Good Manufacturing Practices at U.S. academic centers. Cytotherapy. 2019; 21(7): 782-92.

PubMed Abstract | Publisher Full Text

31. Astori G, Amati E, Bambi F, et al:: Platelet lysate as a substitute for animal serum for the ex-vivo expansion of mesenchymal stem/stromal cells: present and future. Stem Cell Res Ther. 2016; 7(1): 93.

PubMed Abstract | Publisher Full Text | Free Full Text

32. Trojahn Kølle SF, Oliveri RS, Glovinski PV, et al.: Pooled human platelet lysate versus fetal bovine serum-investigating the proliferation rate, chromosome stability and angiogenic potential of human adipose tissue-derived stem cells intended for clinical use. Cytotherapy. 2013; 15(9): 1086-97.

PubMed Abstract | Publisher Full Text

33. Bieback K, Fernandez-Muñoz B, Pati S, et al.: Gaps in the knowledge of human platelet lysate as a cell culture supplement for cell therapy: a joint publication from the AABB and the International Society for Cell \& Gene Therapy. Cytotherapy. 2019; 21(9): 911-24.

PubMed Abstract | Publisher Full Text

34. Martin I, de Boer J, Sensebe L, et al:: A relativity concept in mesenchymal stromal cell manufacturing. Cytotherapy. 2016; 18(5): 613-20. PubMed Abstract | Publisher Full Text

35. Gao F, Chiu SM, Motan DAL, et al: Mesenchymal stem cells and immunomodulation: current status and future prospects. Cell Death Dis. 2016; 7: e2062. PubMed Abstract | Publisher Full Text | Free Full Text

36. Hoogduijn MJ, Lombardo E: Mesenchymal Stromal Cells Anno 2019: Dawn of the Therapeutic Era? Concise Review. Stem Cells Transl Med. 2019; 8(11): 1126-34.

PubMed Abstract | Publisher Full Text | Free Full Text

37. Bieback K, Hecker A, Schlechter T, et al.: Replicative aging and differentiation potential of human adipose tissue-derived mesenchymal stromal cells expanded in pooled human or fetal bovine serum. Cytotherapy. 2012; 14(5): 570-83. PubMed Abstract | Publisher Full Text

38. F Barilani M, Palorini R, Votta G, et al: Central metabolism of functionally heterogeneous mesenchymal stromal cells. Sci Rep. 2019; 9(1): 15420 PubMed Abstract | Publisher Full Text | Free Full Text | F1000 Recommendation

39. Sensebé L: Beyond genetic stability of mesenchymal stromal cells. Cytotherapy. 2013; 15(11): 1307-8. PubMed Abstract | Publisher Full Text

40. Moll G, Geißler S, Catar R, et al:: Cryopreserved or Fresh Mesenchymal Stromal Cells: Only a Matter of Taste or Key to Unleash the Full Clinical Potential of MSC Therapy? Adv Exp Med Biol. 2016; 951: 77-98. PubMed Abstract | Publisher Full Text

41. Schäfer R, Spohn G, Baer PC: Mesenchymal Stem/Stromal Cells in Regenerative Medicine: Can Preconditioning Strategies Improve Therapeutic Efficacy? Transfus Med Hemother. 2016; 43(4): 256-67. PubMed Abstract | Publisher Full Text | Free Full Text

42. F Noronha NC, Mizukami A, Caliári-Oliveira C, et al.: Priming approaches to improve the efficacy of mesenchymal stromal cell-based therapies. Stem Cell Res Ther. 2019; 10(1): 131

PubMed Abstract | Publisher Full Text | Free Full Text | F1000 Recommendation

43. F Chinnadurai R, Copland IB, Patel SR, et al:: IDO-independent suppression of T cell effector function by IFN- $\gamma$-licensed human mesenchymal stromal cells. $J$ Immunol. 2014; 192(4): 1491-501.

PubMed Abstract | Publisher Full Text | F1000 Recommendation

44. Kim DS, Jang IK, Lee MW, et al:: Enhanced Immunosuppressive Properties of Human Mesenchymal Stem Cells Primed by Interferon- $\gamma$. EBioMedicine. 2018; 28: $261-73$.

PubMed Abstract | Publisher Full Text | Free Full Text

45. F Burand AJ, Gramlich OW, Brown AJ, et al:: Function of Cryopreserved Mesenchymal Stromal Cells With and Without Interferon- $\gamma$ Prelicensing is Context Dependent. Stem Cells. 2017; 35(5): 1437-9.

PubMed Abstract | Publisher Full Text | Free Full Text | F1000 Recommendation

46. F Robb KP, Fitzgerald JC, Barry F, et al.: Mesenchymal stromal cell therapy: progress in manufacturing and assessments of potency. Cytotherapy. 2019; 21(3): 289-306.

PubMed Abstract | Publisher Full Text | F1000 Recommendation

47. Leber J, Barekzai J, Blumenstock M, et al:: Microcarrier choice and bead-tobead transfer for human mesenchymal stem cells in serum-containing and chemically defined media. Process Biochem. 2017; 59(Part B): 255-65. Publisher Full Text

48. Pachler K, Lener T, Streif D, et al.: A Good Manufacturing Practice-grade standard protocol for exclusively human mesenchymal stromal cell-derived extracellular vesicles. Cytotherapy. 2017; 19(4): 458-72. PubMed Abstract | Publisher Full Text

49. Viswanathan S, Shi Y, Galipeau J, et al:: Mesenchymal stem versus stromal cells: International Society for Cell \& Gene Therapy (ISCT®) Mesenchymal Stromal Cell committee position statement on nomenclature. Cytotherapy. 2019; 21(10): 1019-24.

PubMed Abstract | Publisher Full Text

50. Prockop DJ: Repair of tissues by adult stem/progenitor cells (MSCs): 
controversies, myths, and changing paradigms. Mol Ther. 2009; 17(6): 939-46. PubMed Abstract | Publisher Full Text | Free Full Text

51. Jung JW, Kwon M, Choi JC, et al:: Familial occurrence of pulmonary embolism after intravenous, adipose tissue-derived stem cell therapy. Yonsei Med J. 2013; 54(5): 1293-6.

PubMed Abstract | Publisher Full Text | Free Full Text

52. Moll G, Ankrum JA, Kamhieh-Milz J, et al: Intravascular Mesenchymal Stromal Stem Cell Therapy Product Diversification: Time for New Clinical Guidelines. Trends Mol Med. 2019; 25(2): 149-63.

PubMed Abstract | Publisher Full Text

53. Coppin L, Sokal E, Stéphenne X: Thrombogenic Risk Induced by Intravascular Mesenchymal Stem Cell Therapy: Current Status and Future Perspectives. Cells. 2019; 8(10). pii: E1160.

PubMed Abstract | Publisher Full Text | Free Full Text

54. Wysoczynski M, Khan A, Bolli R: New Paradigms in Cell Therapy: Repeated Dosing, Intravenous Delivery, Immunomodulatory Actions, and New Cell Types. Circ Res. 2018; 123(2): 138-58.

PubMed Abstract | Publisher Full Text | Free Full Text

55. F Kabat M, Bobkov I, Kumar S, et al.: Trends in mesenchymal stem cell clinical trials 2004-2018: Is efficacy optimal in a narrow dose range? Stem Cells Transl Med. 2020; 9(1): 17-27.

PubMed Abstract | Publisher Full Text | Free Full Text | F1000 Recommendation

56. F Salvadori M, Cesari N, Murgia A, et al.: Dissecting the Pharmacodynamics and Pharmacokinetics of MSCs to Overcome Limitations in Their Clinical Translation. Mol Ther Methods Clin Dev. 2019; 14: 1-15. PubMed Abstract | Publisher Full Text | Free Full Text | F1000 Recommendation

57. Le Blanc K, Davies LC: MSCs-cells with many sides. Cytotherapy. 2018; 20(3): 273-8.

PubMed Abstract | Publisher Full Text

58. F Ankrum JA, Ong JF, Karp JM: Mesenchymal stem cells: Immune evasive, not immune privileged. Nat Biotechnol. 2014; 32(3): 252-60.

PubMed Abstract | Publisher Full Text | Free Full Text | F1000 Recommendation

59. F Cheung TS, Galleu A, von Bonin M, et al: : Apoptotic mesenchymal stromal cells induce prostaglandin E2 in monocytes: Implications for the monitoring of mesenchymal stromal cell activity. Haematologica. 2019; 104(10): e438-e441. PubMed Abstract | Publisher Full Text | F1000 Recommendation

60. F Galleu A, Riffo-Vasquez Y, Trento C, et al.: Apoptosis in mesenchymal stromal cells induces in vivo recipient-mediated immunomodulation. Sci Trans Med. 2017; 9(416). pii: eaam7828.

PubMed Abstract | Publisher Full Text | F1000 Recommendation

61. F Weiss DJ, English K, Krasnodembskaya A, et al.: The Necrobiology of Mesenchymal Stromal Cells Affects Therapeutic Efficacy. Front Immunol. 2019; 10: 1228.

PubMed Abstract | Publisher Full Text | Free Full Text | F1000 Recommendation

62. Moll G, Rasmusson-Duprez I, von Bahr L, et al:: Are Therapeutic Human Mesenchymal Stromal Cells Compatible with Human Blood? Stem Cells. 2012; 30(7): 1565-74.

PubMed Abstract | Publisher Full Text

63. F Oeller M, Laner-Plamberger S, Hochmann S, et al.: Selection of Tissue FactorDeficient Cell Transplants as a Novel Strategy for Improving Hemocompatibility of Human Bone Marrow Stromal Cells. Theranostics. 2018; 8(5): 1421-34. PubMed Abstract | Publisher Full Text | Free Full Text | F1000 Recommendation

64. Badillo AT, Beggs KJ, Javazon EH, et al:: Murine Bone Marrow Stromal Progenitor Cells Elicit an In Vivo Cellular and Humoral Alloimmune Response. Biol Blood Marrow Transplant. 2007; 13(4): 412-22. PubMed Abstract | Publisher Full Text | Free Full Text

65. Zangi L, Margalit R, Reich-Zeliger S, et al.: Direct imaging of immune rejection and memory induction by allogeneic mesenchymal stromal cells. Stem Cells. 2009; 27(11): 2865-74.

PubMed Abstract | Publisher Full Text

66. Lohan P, Treacy O, Griffin MD, et al.: Anti-Donor Immune Responses Elicited by Allogeneic Mesenchymal Stem Cells and Their Extracellular Vesicles: Are We Still Learning? Front Immunol. 2017; 8: 1626.

PubMed Abstract | Publisher Full Text | Free Full Text

67. F García-Sancho J, Sánchez A, Vega A, et al.: Influence of HLA Matching on the Efficacy of Allogeneic Mesenchymal Stromal Cell Therapies for Osteoarthritis and Degenerative Disc Disease. Transplant Direct. 2017; 3(9): e205.

PubMed Abstract | Publisher Full Text | Free Full Text | F1000 Recommendation

68. Skyler JS, Fonseca VA, Segal KR, et al:: Allogeneic Mesenchymal Precursor Cells in Type 2 Diabetes: A Randomized, Placebo-Controlled, Dose-Escalation Safety and Tolerability Pilot Study. Diabetes Care. 2015; 38(9): 1742-9. PubMed Abstract | Publisher Full Text | Free Full Text

69. Packham DK, Fraser IR, Kerr PG, et al.: Allogeneic Mesenchymal Precurso Cells (MPC) in Diabetic Nephropathy: A Randomized, Placebo-controlled, Dose Escalation Study. EBioMedicine. 2016; 12: 263-9. PubMed Abstract | Publisher Full Text | Free Full Text

70. Horwitz EM, Prockop DJ, Fitzpatrick LA, et al: Transplantability and therapeutic effects of bone marrow-derived mesenchymal cells in children with osteogenesis imperfecta. Nat Med. 1999; 5(3): 309-13. PubMed Abstract | Publisher Full Text

71. Ferreira JR, Teixeira GQ, Santos SG, et al:: Mesenchymal Stromal Cell Secretome: Influencing Therapeutic Potential by Cellular Pre-conditioning.
Front Immunol. 2018; 9: 2837

PubMed Abstract | Publisher Full Text | Free Full Text

72. Fontaine $\mathrm{MJ}$, Shih $\mathrm{H}$, Schäfer R, et al:: Unraveling the Mesenchymal Stromal Cells' Paracrine Immunomodulatory Effects. Transfus Med Rev. 2016; 30(1): 37-43. PubMed Abstract | Publisher Full Text

73. Teng X, Chen L, Chen W, et al:: Mesenchymal Stem Cell-Derived Exosomes Improve the Microenvironment of Infarcted Myocardium Contributing to Angiogenesis and Anti-Inflammation. Cell Physiol Biochem. 2015; 37(6): 2415-24. PubMed Abstract | Publisher Full Text

74. DiMarino AM, Caplan Al, Bonfield TL: Mesenchymal stem cells in tissue repair. Front Immunol. 2013; 4: 201

PubMed Abstract | Publisher Full Text | Free Full Text

75. Théry C, Witwer KW, Aikawa E, et al:: Minimal information for studies of extracellular vesicles 2018 (MISEV2018): a position statement of the International Society for Extracellular Vesicles and update of the MISEV2014 quidelines. J Extracell Vesicles. 2018; 7(1): 1535750. PubMed Abstract | Publisher Full Text | Free Full Text

76. F Jeppesen DK, Fenix AM, Franklin JL, et al:: Reassessment of Exosome Composition. Cell. 2019; 177(2): 428-445.e18.

PubMed Abstract | Publisher Full Text | Free Full Text | F1000 Recommendation

77. F Grange C, Skovronova R, Marabese F, et al.: Stem Cell-Derived Extracellular Vesicles and Kidney Regeneration. Cells. 2019; 8(10): pii: E1240.

PubMed Abstract | Publisher Full Text | Free Full Text | F1000 Recommendation

78. Shah R, Patel T, Freedman JE: Circulating Extracellular Vesicles in Human Disease. N Engl J Med. 2018; 379(22): 2180-1.

PubMed Abstract | Publisher Full Text

79. F Tao SC, Rui BY, Wang QY, et al:: Extracellular vesicle-mimetic nanovesicles transport LncRNA-H19 as competing endogenous RNA for the treatment of diabetic wounds. Drug Deliv. 2018; 25(1): 241-55.

PubMed Abstract | Publisher Full Text | Free Full Text | F1000 Recommendation

80. F Witwer KW, Van Balkom BWM, Bruno S, et al.: Defining mesenchymal stromal cell (MSC)-derived small extracellular vesicles for therapeutic applications. J Extracell Vesicles. 2019; 8(1): 1609206.

PubMed Abstract | Publisher Full Text | Free Full Text | F1000 Recommendation

81. Saas P, Daguindau E, Perruche S: Concise Review: Apoptotic Cell-Based Therapies-Rationale, Preclinical Results and Future Clinical Developments. Stem Cells. 2016; 34(6): 1464-73.

PubMed Abstract | Publisher Full Text

82. Bieback K, Kuç S, Schäfer R: Production and quality testing of multipotent mesenchymal stromal cell therapeutics for clinical use. Transfusion. 2019; 59(6): 256.

PubMed Abstract | Publisher Full Tex

83. F Pachler K, Ketterl N, Desgeorges A, et al:: An In Vitro Potency Assay or Monitoring the Immunomodulatory Potential of Stromal Cell-Derived Extracellular Vesicles. Int J Mol Sci. 2017; 18(7): pii: E1413.

PubMed Abstract | Publisher Full Text | Free Full Text | F1000 Recommendation

84. F Thej C, Ramadasse B, Walvekar A, et al:: Development of a surrogate potency assay to determine the angiogenic activity of Stempeucel $\Theta$, a pooled, ex-vivo expanded, allogeneic human bone marrow mesenchymal stromal cell product. Stem Cell Res Ther. 2017; 8(1): 47

PubMed Abstract | Publisher Full Text | Free Full Text | F1000 Recommendation

85. Murgia A, Veronesi E, Candini O, et al:: Potency Biomarker Signature Genes from Multiparametric Osteogenesis Assays: Will cGMP Human Bone Marrow Mesenchymal Stromal Cells Make Bone? PLoS One. 2016; 11(10): e0163629. PubMed Abstract | Publisher Full Text | Free Full Text

86. Bloom D, Bhatia N, Hanley P, et al:: A Reproducible Potency Assay to Measure Differences in MSC-mediated T cell Suppression. Transfusion. 53: 64a-64a. Reference Source

87. F Viganò M, Budelli S, Lavazza C, et al:: Tips and Tricks for Validation of Quality Control Analytical Methods in Good Manufacturing Practice Mesenchymal Stromal Cell Production. Stem Cells Int. 2018; 2018: 3038565.

PubMed Abstract | Publisher Full Text | Free Full Text | F1000 Recommendation

88. F Chinnadurai R, Rajan D, Qayed M, et al.: Potency Analysis of Mesenchymal Stromal Cells Using a Combinatorial Assay Matrix Approach. Cell Rep. 2018; 22(9): 2504-17.

PubMed Abstract | Publisher Full Text | Free Full Text | F1000 Recommendation

89. F Chinnadurai R, Rajakumar A, Schneider AJ, et al.: Potency Analysis of Mesenchymal Stromal Cells Using a Phospho-STAT Matrix Loop Analytical Approach. Stem Cells. 2019; 37(8): 1119-25.

PubMed Abstract | Publisher Full Text | Free Full Text | F1000 Recommendation

90. Boregowda SV, Krishnappa V, Haga CL, et al:: A Clinical Indications Prediction Scale Based on TWIST1 for Human Mesenchymal Stem Cells. EBioMedicine. 2016; 4: 62-73.

PubMed Abstract | Publisher Full Text | Free Full Text

91. Kuci S, Kuci Z, Kollet J, et al.: Genetic Signature of Mesenchymal Stromal Cells Derived from Human Bone Marrow Cd271+Mononuclear Cells. Bone Marrow Transpl. 2014; 49: S191-S192.

92. F Khong SL, Lee M, Kosaric N, et al:: Single-Cell Transcriptomics of Human Mesenchymal Stem Cells Reveal Age-Related Cellular Subpopulation Depletion and Impaired Regenerative Function. Stem Cells. 2019; 37(2): 240-6. PubMed Abstract | Publisher Full Text | F1000 Recommendation 


\section{Open Peer Review}

\section{Current Peer Review Status:}

\section{Editorial Note on the Review Process}

Faculty Reviews are review articles written by the prestigious Members of Faculty Opinions. The articles are commissioned and peer reviewed before publication to ensure that the final, published version is comprehensive and accessible. The reviewers who approved the final version are listed with their names and affiliations.

\section{The reviewers who approved this article are:}

\section{Version 1}

\section{Thomas Ritter}

Regenerative Medicine Institute (REMEDI), College of Medicine, Nursing and Health Sciences, National University of Ireland, Galway, Ireland

Competing Interests: No competing interests were disclosed.

\section{Massimo Dominici} epartment of Medical and Surgical Sciences for Children and Adults, Division of Oncology, UniversityHospital of Modena and Reggio Emilia, Modena, Italy

Competing Interests: No competing interests were disclosed.

\section{Bettina Wilm}

Department of Cellular and Molecular Physiology, University of Liverpool, Liverpool, UK Competing Interests: Bettina Wilm and Karen Bieback individually receive funding from the EU research and innovation programme under the Marie Skłodowska-Curie Actions.

The benefits of publishing with F1000Research:

- Your article is published within days, with no editorial bias

- You can publish traditional articles, null/negative results, case reports, data notes and more

- The peer review process is transparent and collaborative

- Your article is indexed in PubMed after passing peer review

- Dedicated customer support at every stage

For pre-submission enquiries, contact research@f1000.com 